\title{
Investigations on cultural and cellulolytic activity in Pyricularia oryzae Cavara
}

\author{
B Okeke, F Seigle-Murandi ${ }^{\star}$, R Steiman, L Sage \\ Groupe pour l'Étude du Devenir des Xénobiotiques dans l'Environnement (GEDEXE), Laboratoire de Botanique, \\ Cryptogamie, Biologie Cellulaire et Génétique, Université J Fourier, UFR de Pharmacie, (Grenoble I), BP 138, \\ 38243 Meylan Cedex, France
}

(Received 3 September 1991; accepted 6 March 1992)

\begin{abstract}
Summary - The growth of Pyricularia oryzae Cavara was studied on 2 solid complex media, malt and rice extracts, under different conditions. The 2 culture media encouraged growth of the phytopathogen but their effects varied between strains. Statistical analysis showed that the effect of media on the growth of the different strains was non-significant, while inter-strain differences were due to $\mathrm{pH}$. Growth was better at $\mathrm{pH} 6$ and 7 than at $\mathrm{pH} 5$, and was inhibited below 5 and above $37^{\circ} \mathrm{C}$. It was optimum at $28^{\circ} \mathrm{C}$, moderate at $23^{\circ} \mathrm{C}$ and minimum at $15^{\circ} \mathrm{C}$, with very low sporulation or without sporulation, depending on strains. Low relative humidity apparently lowered sporulation in all strains. On synthetic media, nitrate-N as growth nutrient was preferred to ammonium- $N$ by $P$ oryzae. A remarkably better development was observed in synthetic medium containing sodium nitrate in place of ammonium salts. Four strains out of 5 were tested for cellulolytic activity. The levels of cellulose degradation were not consistent in Avicel azure and Cellulose azure for all the strains, and showed various degrees of positive activity.
\end{abstract}

Oryza sativa $=$ rice $/$ rice blast $/$ Pyricularia oryzae $/$ cellulolytic activity

Résumé - Conditions de culture et activité cellulolytique chez Pyricularia oryzae Cavara. La croissance de Pyricularia oryzae Cavara a été étudiée sur 2 milieux solides complexes à base d'extraits de malt et de riz, sous différentes conditions. Ces 2 milieux favorisent le développement du pathogène d'une manière variable selon les souches. L'analyse statistique montre que l'effet du milieu sur la croissance n'est pas significatif alors que les différences entre souches sont dues au pH. La croissance est meilleure à $\mathrm{pH} 6$ et 7 qu'à $\mathrm{pH} 5$ et est inhibée en dessous de $5^{\circ} \mathrm{C}$ et au-dessus de $37^{\circ} \mathrm{C}$. Elle est optimale à $28^{\circ} \mathrm{C}$, modérée à $23^{\circ} \mathrm{C}$ et minimale à $15^{\circ} \mathrm{C}$ avec une sporulation faible ou nulle selon les souches. Sur milieu synthétique $\mathrm{P}$ oryzae préfère l'azote nitrique à l'azote ammoniacal. Le développement est significativement meilleur lorsque le nitrate de sodium remplace les sels d'ammonium. La recherche de l'activité cellulolytique de 4 souches a montré différents niveaux d'activité sur Avicel azure et Cellulose azure.

riz Oryza sativa $=$ riz $/$ pyriculariose $/$ Pyricularia oryzae $/$ activité cellulolytique

\section{INTRODUCTION}

Blast caused by Pyricularia oryzae Cavara, a heterothallic fungus (Yaegashi, 1977), has been identified in most rice growing regions of the world as the most important disease in the crop (Ou, 1985). It has been docu- mented in 85 countries especially in Africa, Asia, America, Australia and parts of Europe (CMI, 1981). Under favourable environmental conditions, particularly temperature and humidity, economic loss may range from very serious to total loss of crops. Based on the part of the plant affected, 3 types of blasts are distinguished: leaf, panicle and neck blasts.

\footnotetext{
* Correspondence and reprints
} 
However, Notteghem (1988) noted that leaf and neck blast constitute the most important damage. The latter provokes total sterility of the panicles. The whole plant may be affected as a result of a die-back phenomenon. The different types of blasts may manifest either in a mixed attack or successively as in cases where leaf blast is know to precede panicle blast (Goto, 1965). Disease severity and loss vary with season and time of infection. The high variability of $P$ oryzae renders chemical control difficult. However, the use of resistant varieties of rice as well as reasonable and adequate chemical control measures have been found very helpful (Notteghem, 1979).

This work is part of a preliminary cultural investigation in our laboratory which is aimed at establishing a base for a major research on the metabolites of fungal origin employable in the control of $P$ oryzae. The growth of the phytopathogen has been compared by using 2 solid complex culture media, malt and rice extracts and 4 other synthetic media to indicate nitrogen source preference. The experiments were carried out under different $\mathrm{pH}$ and temperature conditions. We have also studied the cellulolytic activities of different strains of $P$ oryzae using Cellulose and Avicel azures (Wilding et al, 1967; Coutts and Smith, 1976). The purpose of this approach was to subsequently propose a method for the determination of pathogenicity of strains of phytopathogenic fungi such as $P$ oryzae in terms of their ability to degrade cellulose and hemicellulose which form between 28$50 \%$ of world annual plant biomass (Thompson, 1983).

\section{MATERIALS AND METHODS}

\section{Origin of strains}

Five pathogenic strains of $P$ oryzae were obtained from the Phytopathology Department of the International Cooperation Center in Agronomic Research for Development (CIRAD) in Montpellier, France. Strains 1039 (mat 1-1), 1042 (mat 1-1) and 1054 (mat 1-1) were isolated from rice leaves in France, Japan and Nigeria respectively, while strains 1040 (mat 1-2) and 1041 (mat 1-1) came from Eleusine coracana in Uganda. The 5 strains showed the typical morphological characteristics (Ou, 1985) of $P$ oryzae. They were preserved on dry filter papers after isolation and wrapped in en- velopes sealed in airtight polyethylene sachets. The sachets were preserved at $4^{\circ} \mathrm{C}$.

\section{Culture conditions}

Stock cultures were made on solid malt extract $(1.5 \%)$ medium at $23^{\circ} \mathrm{C}$. The growth of the 5 strains was compared on solid malt extract medium (Difal, Villefranche-sur-Saône, France) (15 g malt extract $+15 \mathrm{~g}$ agar in $1 \mathrm{I}$ of distilled water) and yeast-rice medium $(14 \mathrm{~g}$ rice $+15 \mathrm{~g}$ agar $+4 \mathrm{~g}$ yeast extract). The media were adjusted to $\mathrm{pH} 5$, $\mathrm{pH} 6$ and $\mathrm{pH} 7$. Growth represented as the diameter of the culture Petri dish $(90 \mathrm{~mm})$ covered by each pathogen was measured every other day for 10 days. Strain 1040 was further cultured at the aforementioned $\mathrm{pH}$ and at the following temperatures: $5,15,23,28$ and $37^{\circ} \mathrm{C}$. Daily growth measurements were taken for another 10 days. All measurements were made in 4 replicates. In parallel, the growth of the same strain 1040 was compared in 4 other synthetic media: mineral salts (MS) medium (Saber and Crawford, 1985); MS medium in which ammonium sulfate-nitrogen was replaced with sodium nitrate-nitrogen with equivalent nitrogen content (Eriksson and Johnsrud, 1982), Galzy-Slonimski (GS) medium (1957) and GS medium in which the nitrogen from ammonium sulfate + ammonium dihydrogen phosphate was replaced with sodium nitrate-nitrogen. The replacements were to determine the preferred source of nitrogenous nutrient which is essential for the growth of $P$ oryzae. These culture media were solidified with $15 \mathrm{~g}$ of agar and their $\mathrm{pH}$ adjusted to 5.5 with $1 \mathrm{~N}$ phosphoric acid. Sterilization was performed in an autoclave at $120^{\circ} \mathrm{C}$ for $20 \mathrm{~min}$. The culture media were poured into Petri dishes after adequate cooling. Calibrated samples (2 $\mathrm{mm}$ diam) of strains (mycelia and spores) were centrally inoculated.

\section{Cellulolytic activity}

Cellulolytic activities of the 5 strains of $P$ oryzae were evaluated against 2 different substrates: cellulose azure (Sigma, St Louis, USA) and Avicel azure, produced locally according to the method described by Wilding et al (1967) using rimazole brilliant blue (RBB) (Calbiochem, Behring, USA).

The method used for the evaluation of cellulose degradation was developed by Peterson and modified by Coutts and Smith (1976). It is based on the diffusion of RBB through the Coutts and Smith medium due to the breakdown of covalent bonds between the molecules. The significance of the cellulase enzyme activity was obtained by comparison with a standard curve made from an increasing concentration of RBB : 0 to $0.25 \mathrm{mg} / \mathrm{l}$. The absorbance of each concentration was read at $595 \mathrm{~nm}$. 
Two $\mathrm{ml}$ of Coutts and Smith medium was poured into a set of 5-ml test tubes and cooled. Another 2 sets of the same medium were prepared with Cellulose and Avicel azure respectively added to make a final concentration of $2 \% .0 .5 \mathrm{ml}$ each of either Cellulose or Avicel azure was added to the tubes containing the solid culture medium. After solidification of the upper layers, equal samples of the $5 P$ oryzae strains were separately inoculated in duplicate. The cultures were incubated at $23^{\circ} \mathrm{C}$ for 18 days in Avicel azure and 11 days in cellulose azure, sufficient time for maximum diffusion of BRB in some of the tubes. Color changes due to the diffusion of RBB were compared with a standard and their optical densities were extrapolated from the standard curve.

\section{RESULTS AND DISCUSSION}

The in vitro nutritional requirements of $P$ oryzae under various physicochemical conditions have been extensively reviewed by Tanaka (1965). It has, however, become necessary to reexamine some of these factors with the aim of selecting a suitable culture medium. The growth of 5 different strains of the pathogen was observed on solid malt extract and rice extract media at $\mathrm{pH} 5,6$ and 7 , all at $28^{\circ} \mathrm{C}$. From statistical analysis (ANOVA with $P=0.01$ ) the effect of culture media and $\mathrm{pH}$ varied with strains. When the strains were considered separately, the effect of media on growth was not significant. Inter-strain differences were particularly due to $\mathrm{pH}$. Generally growth was least at $\mathrm{pH} 5$ and differed significantly from those at $\mathrm{pH} 6$ and 7. Tanaka (1965) observed that $P$ oryzae is basophilic and that its growth is limited at $\mathrm{pH} 4-5$.

In all strains, more vertical mycelial growth occurred on rice than on malt at the various $\mathrm{pH}$. Thick white mycelia grew on rice medium compared with the dark brown and sparsely distributed mycelia on malt medium. Spore production was variable between the strains in all culture conditions. Strain 1040 did not sporulate either in malt or in rice media, while strain 1054 produced very few spores in rice medium at pH 6 only. Strains 1039, 1041 and 1042 either did not sporulate or produced very few spores. It was rather difficult to relate this non-sporulation or low spore production to either the effect of the media, the $\mathrm{pH}$ or temperature, or even the differences in strains as the pattern was generally irregular. However, this condition could be due to the level of am- bient relative humidity which was between 70 $80 \%$. Valent (1990) observed that sporulation by $P$ oryzae could be kept low by maintaining the relative humidity at $85 \%$ or below. Elsewhere it was noted that sporulation was lower at $89-90 \%$, and never occurred at less than $88 \%$ (Hemmi and Imura, 1939). Further culturing of strain 1040 in the different synthetic media showed that the GS and the MS media were not favourable to the growth of the blast fungus which attained only $28 \%$ and $11 \%$ of the control in each medium respectively, 10 days after inoculation. When $\mathrm{NH}_{4}{ }^{+}$ion in the normal GS medium was substituted with $\mathrm{NO}_{3}$ anion growth increased, but remained less than the control by about $18 \%$. This observation is in accordance with that of Tanaka (1965) who concluded that nitrate was a preferred source of nitrogen as an essential growth factor for $P$ oryzae. This was attributed to the consequential fall of $\mathrm{pH}$ in the medium following an initial preferential absorption of ammonium ion to nitrate anion as found when ammonium nitrate was used as the only nitrogen source. More spores were observed in the nitrate nitrogen-based GS medium than in that of ammonium nitrogen. Growth only slightly improved in the MS medium with reduced sporulation. The blast fungus grows best at $28^{\circ} \mathrm{C}$ when the relative humidity is $93 \%$ or above (Ou, 1985). We have also obtained best growth of strain 1040 at $28^{\circ} \mathrm{C}$, relative humidity notwithstanding. The fungus did not grow below $5^{\circ} \mathrm{C}$ and above $37^{\circ} \mathrm{C}$.

For obvious industrial and commercial reasons, particularly for fermentation and waste treatments, the ability of many microorganisms to degrade cellulose has been examined by many workers. Ljungdahl and Eriksson (1985) gave a list of some of the most promising ones including fungi. In the last 2 decades, it has been increasingly considered that the cellulase enzyme complex plays an important if not primary role in the process of penetration, infection and the spread of disease lesion in plants. This hypothesis is supported by the fact that a greater part of plant materials is composed of cellulose, hemicellulose and lignin. As advanced by Sudo et al $(1973,1976,1977)$, host plant cell wall cellulose degradation by $P$ oryzae might be used to classify pathogenic strains of the parasite. Of the 5 strains of $P$ oryzae investigated, 4 strains degraded both Avicel azure and Cellulose azure. Strain 1054 did not degrade either Avicel or Cellulose azure. The rate of 
degradation as measured by the optical density (OD) values was highly correlated $\left(R^{2}=\right.$ 0.97-0.99) between both types of cellulose. However, the consistency expected in the ability of a strain to hydrolyse Avicel azure, a replica of native cellulose, and Cellulose azure, a pseudo-type, was not evident. Strain 1042 had the highest activity in Avicel azure while the most active in Cellulose azure was strain 1039. These differences may be due to the variations in the structure of the 2 types of carbohydrates in relation to the proportion, availability and composition of the cellulase enzyme complex existing in each strain. Avicel azure (semi-crystalline cellulose) is apparently degraded by the synergistic action of cellulolytic enzyme complex (Streamer et al, 1975; Henrissat and Chanzy, 1986) which consists of : endo-1,4- $\beta$-glucanases (EC 3.2.1.4) which breaks $1,4-\beta$-glucosidic bonds of the cellulose chain, exo-1,4- $\beta$-glucanases (EC 3.2.21) splitting either cellobiose or glucose from the non reducing end of cellulose and 1,4- $\beta$-glucosidase ( $\beta-1,4-D$-glucan cellobiohydrolase) (EC 3.2.1.91) which hydrolyses cellobiose and water-soluble cellodextrins to glucose. Although Avicel azure may not be hydrolysed by either endo- or exo- glucanases acting individually, Cellulose azure (amorphous cellulose) can be hydrolysed by the separate action of each enzyme (Eriksson and Johnsrud, 1982, Henrissat and Chanzy, 1986). Generally the $P$ oryzae strains used may be said to be weakly cellulolytic, degradation of Avicel and cellulose azure having started at 7-8 days and 5-6 days respectively.

Although interstrain variability in the ability to degrade cellulose materials has been observed, it is apparently too early to attempt to make a relation between cellulose hydrolysis of each strain and its pathogenicity. Further experiments with more strains of $P$ oryzae and subsequent greenhouse inoculation of rice plants have been planned. This will enable us to compare the 2 results and to reach a conclusion regarding pathogenicity in relation to cellulose hydrolysis.

\section{ACKNOWLEDGMENT}

We thank JL Notteghem of the Phytopathology Department, IRAT, International Cooperation Center in Agronomic Research for Development (CIRAD), Montpellier, France, who kindly supplied the strains of Pyricularia oryzae used in this study.

\section{REFERENCES}

CMI/Commonwealth Mycological Institute (1981) Distribution Maps of Plant Diseases, 6th edn, 51

Coutts AD, Smith RE (1976) Factors influencing the production of cellulase by Sporotrichum thermophile. App/ Environ Microbiol 30, 819-825

Eriksson KE, Johnsrud C (1982) Mineralisation of carbon. In: Experimental Microbial Ecology (Hollander A, ed) Plenum Press, NY, 134-153

Galzy P, Slonimski P (1957) Variations physiologiques de la levure au cours de la croissance sur l'acide lactique comme seule source de carbone. CA Acad Sci Ser D 245, 2423-2426

Goto K (1965) Estimating losses from rice blast in Japan. In: The Rice Blast Disease. Proc Symp Int Rice Res Inst, The Philippines, July 1963

Hemmi T, Imura J (1939) On the relation of air humidity to conidial formation in the rice blast fungus, Pyricularia oryzae, and the characteristics in the germination of conidia produced by the strains showing different pathogenicity. Ann Phytopathol Soc Jpn 9, 147-156

Henrissat B, Chanzy H (1986) Enzymatic breakdown of cellulose crystals. In: Cellulose Structure, Modification and Hydrolysis (Young RA, Rowell RM, eds) A Wiley-Interscience Publ, New York, 337-347

Ljungdahl LG, Eriksson KE (1985) Ecology of microbial cellulase degradation. In: Advances in Microbial Ecology (Marshall KC, ed) Plenum Publ Corp, New York, vol 8, 237-248

Notteghem JL (1979) Application en Afrique des méthodes de lutte contre la pyriculariose. In: Sém ADRAO Les Méthodes Intégrées de Lutte Contre les Insectes Parasites et Maladies du Riz en Afrique de l'Ouest. Bobo-Dioulasso, 1-12

Notteghem JL (1988) La création de variété résistante: cas du riz et de la pyriculariose. Bull Soc Bot Fr 136; Actual Bot 3/4, 227-237

Ou SH (1985) Rice Diseases. Commonwealth Mycological Institute, Kew, UK

Saber DL, Crawford RL (1985) Isolation and characterization of Flavobacterium strains that degrade pentachlorophenol. Appl Environ Microbiol 50, 1512-1518

Streamer M, Eriksson KE, Pettersson B (1975) Extracellular enzyme system utilised by the fungus Sporotrichum pulverulentum (Chrysosporium lignorum) for the breakdown of cellulose. Eur $J$ Biochem 59, 607-613

Sudo T, Nagayama H, Tamari K (1973) Occurrence and some properties of cellulase in the filtrate of conidiospores and mycelia of Pyricularia oryzae Cavara. Agric Biol Chem 37, 1651-1659 
Sudo T, Nagayama H, Tamari K (1976) Partial purification of intra- and extracellular cellulases from Pyricularia oryzae: with reference to optimum $\mathrm{pH}$ at alkaline side. Agric Biol Chem 40, 1509-1514

Sudo T, Nagayama H, Tamari K (1977) Effects of $\mathrm{NaCl}$ on cellulase activities of various strains of Pyricularia oryzae. Agric Biol Chem 41, 597-598

Tanaka S (1965) Nutrition of Pyricularia oryzae in vitro. In: The Rice Blast Disease. Proc Symp Int Rice Res Inst, July 1963

Thompson NS (1983) Hemicellulose as a biomass resources. In: Wood and Agriculture Residues
(Soltes EJ, ed) Academic Press, New York, 101119

Valent B (1990) Rice blast as a model system for plant pathology. Phytopathology 80, 33-36

Wilding P, Rinderrnecht $\mathrm{H}$, Haverback BJ (1967) A new method for the determination of $\alpha$-amylase. University of Southern California School of Medicine, Los Angeles, CA

Yaegashi H (1977) On the sexuality of blast fungi, Pyricularia spp. Ann Phytopathol Soc Jpn 43, $432-439$ 